\title{
Chapter 6 \\ Glacial to Holocene Paleoceanographic and Continental Paleoclimate Reconstructions Based on ODP Site 1233/GeoB 3313 Off Southern Chile
}

\author{
Frank Lamy and Jérome Kaiser
}

\begin{abstract}
ODP Site /GeoB 3313 located at the upper continental slope off southern Chile $\left(41^{\circ} \mathrm{S}\right)$ is ideally located to study latitudinal shifts of atmospheric and oceanographic circulation off southwestern South America. Extraordinarily high sedimentation-rates allow for high resolution reconstructions and detailed comparisons of various continental climate and paleoceanographic proxy records within the same archive avoiding problems linked to age model uncertainties. We discuss the major paleoclimatic findings of Site 1233/GeoB 3313 in chronological order from the last glacial to the Holocene within the regional context and explore links to tropical and high southern latitude records. During the last glacial, sea surface temperatures (SSTs) off southern Chile were about $4.5^{\circ} \mathrm{C}$ colder than today and $\sim 6-7^{\circ} \mathrm{C}$ colder than during the early Holocene maximum. Deglacial warming started at $\sim 18.8 \mathrm{kyr}$ BP with a $\sim 2$-kyr-long increase of nearly $5^{\circ} \mathrm{C}$ and was followed by relatively stable SSTs until the beginning of a second warming step of $\sim 2^{\circ} \mathrm{C}$ during the early halve of the Northern Hemisphere Younger Dryas cold period. Maximum warm conditions in the early Holocene $(\sim 12-9 \mathrm{kyr} \mathrm{BP})$ were followed by a gradual decline towards modern SSTs in the Late Holocene. The paleoceanographic changes and related regional continental climate variations since the last glacial are primarily controlled by latitudinal shift of both the oceanographic and the atmospheric circulation systems in the southeast Pacific. In general, they appear to be closely linked to changes in the Southern Ocean and Antarctica.
\end{abstract}

Keywords Continental paleoclimate $\cdot$ Holocene $\cdot$ Last glacial · Paleoceanography Southeast Pacific · Termination 1

\footnotetext{
F. Lamy $(\otimes)$

Alfred-Wegener-Institut (AWI) Bremerhaven, 27515, Bremerhaven, Germany, e-mail: frank.lamy@awi.de
} 


\subsection{Introduction}

The Chilean continental margin provides a key region for studying natural variability of globally important atmospheric and oceanic circulation members of the Southern Hemisphere since the last glacial maximum and beyond. These primarily include the Antarctic Circumpolar Current (ACC) approaching South America around $40-45^{\circ} \mathrm{S}$ and flowing then northward along the continental margin as the Peru-Chile (PCC) or Humboldt Current and the Southern Westerly Wind belt (SWW) (Fig. 6.1). Past changes in the strength and latitudinal position of the ACC and SWW are supposed to play a major role in explaining global climate changes for example through their impact on atmospheric $\mathrm{CO}_{2}$ contents on a large variety

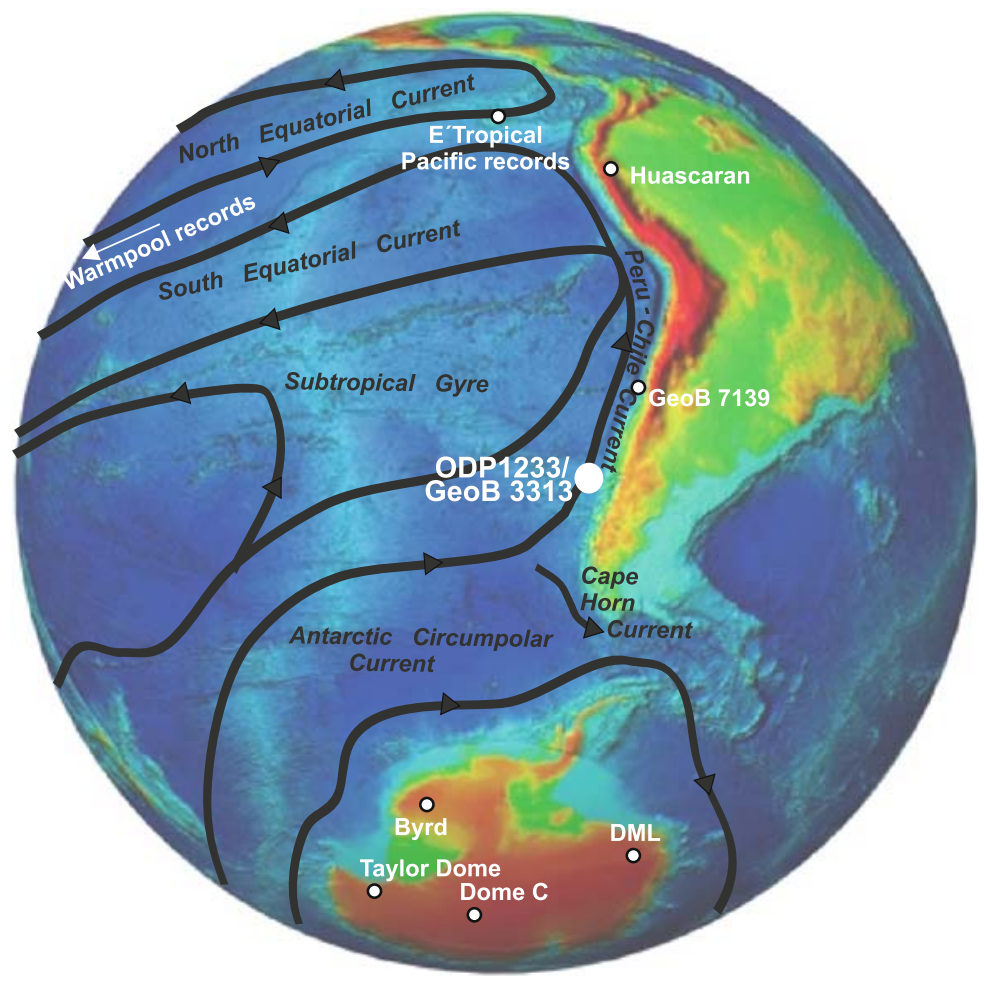

Fig. 6.1 Map of the Pacific and adjacent areas showing major surface currents (after Tomczak and Godfrey (2003)) and the location of marine sediment cores (several cores from the IndoPacific warmpool (Stott et al. 2004; Visser et al. 2003); TR163-19 and V21-30 from the eastern tropical Pacific (Koutavas et al. 2002; Lea et al. 2006); GeoB 7139 off north-central Chile (De PolHolz et al. 2006); ODP 1233/GeoB 3313 off southern Chile; Antarctic ice-cores (Byrd (Blunier and Brook 2001); Dome C (EPICA Community Members 2004); Dronning Maud Land (DML) (EPICA Community Members 2006); Taylor Dome (Steig et al. 1998)), and the Andean ice-core Huascaran (Thompson et al. 1995) discussed in the paper 
of time-scales ranging from decadal to orbital scale (e.g., Toggweiler et al. 2006; Yin 2005).

Compared to other regions of the Southern Hemisphere, marine sediments along the continental margin off Chile have been relatively thoroughly studied after a number of international research cruises during the last decade (e.g., RV SONNE cruises 102 and 156; RV MARION DUFRESNE cruise "Pachiderme" and Ocean Drilling Project (ODP) Leg 202). The presently existing network of sediment cores along the Chilean margin yielded important contributions to improve our understanding of Late Quaternary terrestrial climate changes in Chile (e.g., Hebbeln et al. 2007; Lamy et al. 2001; Lamy et al. 1998b; Lamy et al. 1999; Stuut and Lamy 2004) and the paleoceanography of the adjacent PCC (e.g., Hebbeln et al. 2002; Kim et al. 2002; Mohtadi and Hebbeln 2004). These findings are summarized in two recent review articles (Marchant et al. 2007; Stuut et al. 2006).

Here, we focus on results based on ODP Site 1233 (and site survey core GeoB 3313-1) located at the upper continental slope off southern Chile $\left(41^{\circ} \mathrm{S}\right)$ (Fig. 6.1). This site received particular interest because the $\sim 70$-kyr-old sequence has been recovered continuously with the Advanced Piston Coring System and extends over $\sim 135 \mathrm{~m}$ composite core depth, resulting in unprecedented high sedimentation rates for the South Pacific. The site is ideally located to compare past variations of both surface and deep ocean water masses to high southern latitudes (e.g., Antarctic icecores) (Fig. 6.1). Modern SST gradients within the northernmost ACC are very large and intimately linked to the northern margin of the SWW, making this region very sensitive to latitudinal shifts of atmospheric and oceanographic circulation. Furthermore, Site 1233 is located close to the southern Chilean coast $(\sim 40 \mathrm{~km})$ and close to the northwestern margin of the glacial Patagonian Ice Sheet (PIS), which occupied a large area of southernmost South America during the last glacial (Fig. 6.2). Thus, this unique location allows detailed comparison of various continental climate and paleoceanographic proxy records within the same archive and therefore avoids problems linked to age model uncertainties. A number of different proxy records from ODP Site 1233 have been published within the past years including alkenone and radiolarian-based sea-surface temperature reconstructions (Kaiser et al. 2007; Kaiser et al. 2005; Lamy et al. 2007; Lamy et al. 2004; Pisias et al. 2006), terrestrial sediment input and pollen-based continental climate studies (Heusser et al. 2006; Kaiser et al. 2007; Lamy et al. 2004; Pisias et al. 2006), and nitrogen isotope analyses (Martinez et al. 2006). The major findings of these studies are summarised in this review article.

\subsection{Regional Setting}

Site 1233 and gravity core GeoB $3313-1\left(41^{\circ} 00 / \mathrm{S} ; 74^{\circ} 27^{\prime} \mathrm{W}\right)$ are both located $38 \mathrm{~km}$ offshore at $838 \mathrm{~m}$ water depth in a small forearc basin on the upper continental slope off Southern Chile (Fig. 6.2) (Mix et al. 2003). The area is characterized by a 30-60 km wide shelf, which becomes significantly wider south of $42^{\circ} \mathrm{S}$ in the Chilean fjord region (Scholl et al. 1970). The upper continental slope is moderately 
Fig. 6.2 More detailed location of ODP Site 1233/GeoB 3313 off Southern Chile. Full lines indicate the modern annual mean SST distribution (data from the NOAA-CIRES Climate Diagnostics Center; http://www.cdc.noaa.gov/index.html) together with a simplified view of the major current systems $(\mathrm{PCC}=$ Peru-Chile Current; $\mathrm{ACC}=$ Antarctic Circumpolar Current; $\mathrm{CHC}=$ Cape Horn Current) and the modern mean position of the Southern Westerly Winds (SWW). Further shown are the location of presently existing Andean icefields (black areas) and the limits of the Patagonian Ice Sheet (PIS) during the Last Glacial Maximum as derived from field evidences (dotted line)

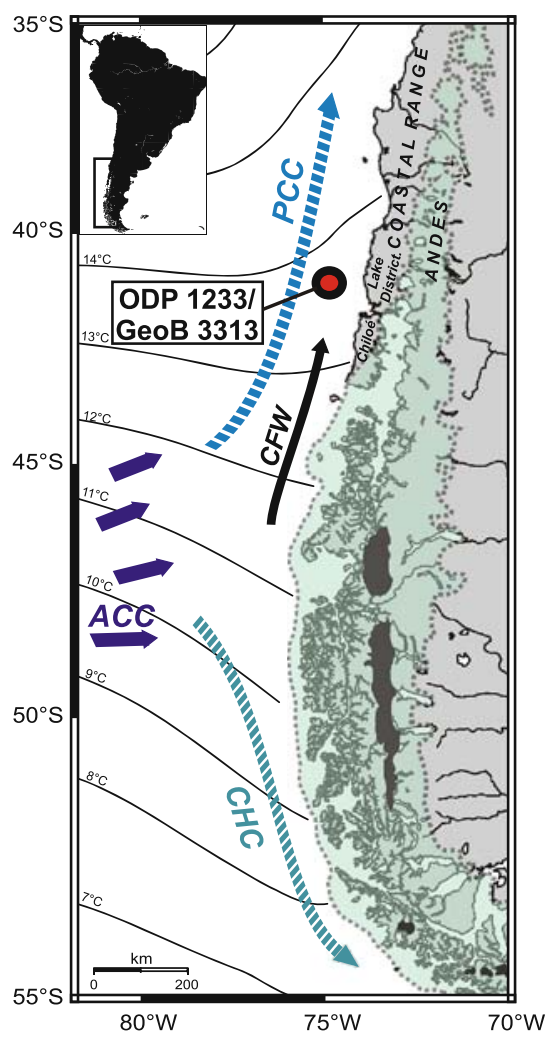

inclined. Thick sheet-flow turbidites bury the Peru-Chile trench as a bathymetric feature in this region, while turbidity currents are more channelized on the upper slope (Thornburg and Kulm 1987a). Site 1233 is located away from these pathways of major turbidity currents.

The site is located within the northernmost boundary of the Antarctic Circumpolar Current (ACC) at the origin of the Peru-Chile Current (PCC) (Fig. 6.2). The ACC brings cold, relatively fresh, nutrient-rich, Subantarctic Surface Water originating from the region north of the Subantarctic Front. At $\sim 43^{\circ} \mathrm{S}$, the ACC splits into the PCC flowing northward and the Cape-Horn Current $(\mathrm{CHC})$ turning towards the south (Strub et al. 1998; Tomczak and Godfrey 2003). The mean annual SST at the coring site is $\sim 14^{\circ} \mathrm{C}$ and varies between $\sim 11^{\circ} \mathrm{C}$ in winter and $\sim 16^{\circ} \mathrm{C}$ in summer, i.e. a seasonal amplitude of $\sim 5^{\circ} \mathrm{C}$. Linked to the northern boundary of the ACC, steep latitudinal SST gradients occur just southward of Site 1233, whereas further north the isotherms run more longitudinally marking the cold water advection by the PCC and, to a lesser extent, the effects of increasing coastal upwelling towards the central and northern Chilean margin (Fig. 6.2) (Strub et al. 1998; Tomczak and Godfrey 2003). There, cold waters $\left(11-14^{\circ} \mathrm{C}\right)$ coming from the equatorial latitudes 
through the Gunther Undercurrent (GUC) are brought to the surface by upwelling. Five main upwelling cells determined by the topography are presently observed off central and northern Chile, at $\sim 23^{\circ}, 27^{\circ}, 30^{\circ}$ and $35^{\circ}-38^{\circ} \mathrm{S}$ (Strub et al., 1998).

The steepest SST gradient within the ACC is related to the main atmospheric circulation member of the Southern Hemisphere, the SWW (Streten and Zillman 1984). This intense and powerful circulation, annually centered around $50^{\circ} \mathrm{S}$, results from the strong thermal gradient and atmospheric pressure difference between cold air masses over Antarctica and the warmer air and water masses in the subtropical regions (Hobbs et al. 1998). In southernmost South America, the SWW and associated storm tracks bring heavy rainfalls, e.g. an annual mean greater than $2000 \mathrm{~mm}$ in Puerto Montt $\left(41^{\circ} \mathrm{S}\right.$ ), and prevent upwelling south of $42^{\circ} \mathrm{S}$ (Strub et al. 1998; Tomczak and Godfrey 2003). Trenberth (1991) has described the modern seasonal fluctuation of the storm tracks associated to the SWW. In summer, the storm track activity can be as strong as in winter, but is located slightly equatorward of its winter position, and is concentrated in a tight band centered around $49-50^{\circ} \mathrm{S}$. In winter, storm track activity extends over a broader range of latitudes and is centered $\sim 2^{\circ}$ poleward. The strong SST gradients associated with the ACC are shifted of $\sim 5^{\circ}$ in latitude northward from their summer position.

The proximity of Site 1233 (GeoB 3313) to the Chilean coast allows following changes in the amount and composition of the terrigenous sediment input in response to rainfall changes and variations in the extent of inland glaciation (Fig. 6.2). The modern climate conditions around $41^{\circ} \mathrm{S}$ are characterized by a humid temperate climate with year round precipitation peaking in austral winter (Miller 1976). The area lies within the transition zone of the summer dry Mediterranean climate north of $37^{\circ} \mathrm{S}$ and year round humid conditions with heavy precipitation south of $42^{\circ} \mathrm{S}$. Rainfall originates from the frontal passages of the SWW and increases strongly to the south making the region very sensitive to latitudinal shifts of the wind belt. Due to the orographic rising of moist Pacific air-masses, rainfall in the Andes is significantly higher than in low elevation areas.

Interannual rainfall variability is strongly linked to the El Niño-Southern Oscillation (ENSO) phenomena and related changes in the strength and position of the Subropical High Pressure cell (STH) (Montecinos and Aceituno 2003; Ruttlant and Fuenzalida 1991). During La Niña events, the STH is consistently strong throughout the year. The storm tracks linked to the SWW remain south of $45^{\circ} \mathrm{S}$ reducing rainfall in the mid-latitudes. Conversely, the STH is weakened during an El Niño event, allowing an equatorward shift of the SWW and a greater cyclonic activity in the Chilean mid-latitudes. Based on monthly data from weather stations in Chile $\left(30^{\circ}-41^{\circ} \mathrm{S}\right)$ for the $1958-1999$ period, Montecinos and Aceituno (2003) have studied the seasonality of ENSO-related rainfall variability. During El Niño events, the precipitations are above the average between $30^{\circ}-38^{\circ} \mathrm{S}$ in austral winter and spring. A rainfall deficit is observed from $38^{\circ}$ to $41^{\circ} \mathrm{S}$ in summer, when El Niño development is maximum. Opposite precipitation anomalies characterize La Niña events.

Three main physiographic features (the Coastal Range, the Chilean Longitudinal Valley, and the Andes) characterize the continental hinterland around $41^{\circ} \mathrm{S}$ 
(Fig. 6.2). The Coastal Range with elevations generally below $500 \mathrm{~m}$ is dominated by primarily low-grade metamorphic rocks (Thornburg and Kulm 1987b). The Central Valley is filled with up to $4,000 \mathrm{~m}$ thick alluvial sediments. The Andes reach elevations of 2,000-3,000 m. The lower parts mainly consist of iron-poor plutonic basement rocks, while the high Andes are dominated by iron-rich basaltic to andesitic volcanics resulting from Pliocene to recent volcanic activity (Thornburg and Kulm 1987b). Various small rivers drain the Coastal Range within the study area. Larger rivers originating in the Andes flow into the ocean north and south of the core position in the region of Puerto Montt. Therefore, terrigenous sediments on the continental slope can be expected to contain both a Coastal Range and Andean source rock signal.

While the modern Patagonian ice-fields are restricted to southernmost Chile (between $\sim 47$ and $52^{\circ} \mathrm{S}$ ), during the Last Glacial Maximum (Last Glacial Maximum) the Patagonian ice-sheet (PIS) extended much further north and reached the island of Chiloé directly south of Site 1233 (Fig. 6.2). Therefore, the site is located in an ideal position to monitor PIS extent variations by recording compositional changes in the regional terrigenous sediment input to the continental margin (Kaiser et al. 2007; Lamy et al. 2004). Glacial erosion processes strongly enhanced the glaciofluvial sediment flux from Fe-rich basaltic volcanics in the Andes during the last glacial. Ice-sheet advances provided more Fe-rich material, being subsequently transported to the continental margin by rivers. Another important regional hydrographic feature off southern Chile that can be used to reconstruct past changes in continental freshwater input is the low-salinity surface water tongue originating from the high fresh water supply to the Chilean fjord region (Strub et al. 1998). This low-salinity Chilean Fjord Water mass (CFW) flows northward within 150-200 km off the coast (Fig. 6.2).

\subsection{Material and Methods}

Site 1233 was drilled during ODP Leg 202 and gravity core GeoB 3313-1 during German R/V Sonne cruise 102 (Hebbeln and Shipboard Scientists 1995; Mix et al. 2003). Five Advanced Piston Corer holes were drilled at Site 1233 to ensure a complete stratigraphic overlap between cores from different holes. Detailed comparisons between high-resolution core logging data performed shipboard demonstrated that the entire sedimentary sequence to $116.4 \mathrm{~m}$ below surface (mbsf) was recovered. Based on these data, a composite sequence (the so-called splice) was constructed representing $135.65 \mathrm{~m}$ composite depth (mcd). The complete recovered sequence at Site 1233 covers the past $\sim 70$ kyr whereas $\sim 8$-m-long gravity core GeoB 3313-1 extends only back to $\sim 8 \mathrm{kyr} \mathrm{BP}$. We are here discussing data since $\sim 25 \mathrm{kyr} \mathrm{BP}$ (thus including the global Last Glacial Maximum (19-23 kyr BP (Mix et al. 2001)), Termination 1, and the Holocene). This interval represents the uppermost $\sim 40 \mathrm{mcd}$ at Site 1233.

Sediments are dominated by terrigenous components (clay and silty clay) with varying but generally small amounts of calcareous and siliceous components. 
Respectively, calcium carbonate concentrations and organic carbon contents range from 1 to $11 \mathrm{wt} \%$ (average $=5.4 \mathrm{wt} \%$ ) and from 0.4 to $2.5 \mathrm{wt} \%$ (average $=0.9 \mathrm{wt} \%$ ) (Martinez et al. 2006; Mix et al. 2003). Organic carbon contents are substantially lower between 30 and $40 \mathrm{mcd}(0.4-1 \mathrm{wt} \%)$ in comparison to the top of the core (up to $2.5 \mathrm{wt} \%$ ). A number of different studies have been done on Site 1233 including primarily alkenone sea surface temperature (SST) giving an approximation of the annual mean temperature between 0-10 m water depth (e.g., Müller et al. 1998), paleosalinity and paleoproductivity reconstructions as well as terrigenous sediment input parameters (XRF scans, clay mineralogy, grain-sizes) and pollen. Details on the methods can be found in the original publications (Heusser et al. 2006; Kaiser et al. 2007; Kaiser et al. 2005; Lamy et al. 2001; Lamy et al. 2007; Lamy et al. 2004; Lamy et al. 2002; Martinez et al. 2006; Pisias et al. 2006).

The age models for both the younger part of the Site 1233 sequence and gravity core GeoB 3313-1 are based on radiocarbon dating. Core GeoB 3313-1 has been dated by $7{ }^{14} \mathrm{C}$ accelerator mass spectrometry (AMS) dates reaching back to $\sim 8 \mathrm{kyr}$ BP (Lamy et al. 2001). This age model has been transferred to the uppermost $\sim 9$ mcd of the Site 1233 sequence using magnetic susceptibility and Ca content records (Kaiser et al. 2005). Below, 18 further ${ }^{14} \mathrm{C}$-AMS dates provide a reliable age model down to $25 \mathrm{kyr}$ BP (Lamy et al. 2007). All radiocarbon ages have been converted to calendar years assuming a constant reservoir age of 400 years (for a detailed discussion see Lamy et al. (2004, 2007)), primarily using the INTCAL04 calibration curve (Reimer et al. 2004). An exception is the interval between $\sim 12,500$ to $\sim 14,500{ }^{14} \mathrm{C}$ years BP where the INTCAL04 calibration curve is poorly constrained and radiocarbon data from the Cariaco basin (Hughen et al. 2004) and the Northwest Pacific (Sarnthein et al. 2006) suggest the presence of a radiocarbon plateau lasting from $\sim 12,900 \sim$ to $\sim 13,300{ }^{14} \mathrm{C}$ years $\mathrm{BP}(\sim 15.7-\sim 17 \mathrm{kyr} \mathrm{BP})$. Therefore, we applied in this interval the CalPal_SFCP_2005 (www.calpal.de) calibration curve which is primarily based on the Cariaco basin record (Hughen et al. 2004) (for details refer to Lamy et al. (2007)). The resulting mean sedimentation rates range between $\sim 1.4$ $\mathrm{m} / \mathrm{kyr}$ in the Holocene to an average of $\sim 2.2 \mathrm{~m} / \mathrm{kyr}$ during the glacial. These high sedimentation rates are consistent with strong fluvial discharge in response to heavy continental rainfall in southern Chile during the Holocene (Lamy et al. 2001). During the last glacial, the continental hinterland of Site 1233 was extensively glaciated as the PIS advanced towards the north (Denton et al. 1999b) explaining even higher terrestrial input through glacial erosion processes (Lamy et al. 2004).

\subsection{Results and Discussion}

In the following we discuss the major findings of Site 1233/Geo 3313 in chronological order from the last glacial to the Holocene. In each chapter, we first summarize and review the evidences based on our site, discuss them within the regional framework including other marine records from the Chilean margin and terrestrial data-sets (land-ocean correlations), and finally relate these findings to tropical and high southern latitude records in order to derive larger-scale implications and 
pattern. Radiocarbon ages of the other records shown and discussed in this chapter have been calibrated in the same way as our Site 1233 records.

\subsubsection{Glacial}

\subsubsection{Regional Aspects}

During the last glacial, SSTs off southern Chile were about $4.5^{\circ} \mathrm{C}$ colder than modern SSTs and $\sim 6-7^{\circ} \mathrm{C}$ colder than during the early Holocene maximum (Fig. 6.3). The record shows a pronounced millennial-scale variability of $2-3^{\circ} \mathrm{C}$ over the glacial interval ( 45-19 kyr BP) (Kaiser et al. 2005; Lamy et al. 2004). The global Last Glacial Maximum is not well defined in the record. Instead, we observe two millennial-scale SST minima during this interval, one close to $22.5 \mathrm{kyr}$ $\mathrm{BP}$, and a second at $\sim 19 \mathrm{kyr} \mathrm{BP}$ directly before the initiation of the deglacial warming (Fig. 6.3) (Lamy et al. 2007). A pollen assemblages study on Site 1233 sediments suggests a significant expansion of subantarctic vegetation type during the last glacial (Fig. 6.4) (Heusser et al., 2006). Based on similar pollen reconstruction onshore, Heusser and Heusser (2006) deduced that summer air temperature (using transfer functions) was around $8-9^{\circ} \mathrm{C}$ at $41^{\circ} \mathrm{S}$ during the last glacial, in close agreement with the SST results.

Fig. 6.3 Site 1233 SST record compared to proxy data taken for changes in the extent of the PIS (after Kaiser et al. 2007; Lamy et al. 2004).

(A) Iron record (inverted scale), high values indicate ice sheet advances with location of major glacier maxima as dated on land (Denton et al. 1999b; Kaplan et al. 2004). (B) Alkenone SST record (Lamy et al. 2007). (C) Paleosalinity data, dashed line indicates beginning of rapid melting after the final PIS maxima at $\sim 17.8 \mathrm{kyr} \mathrm{BP}$

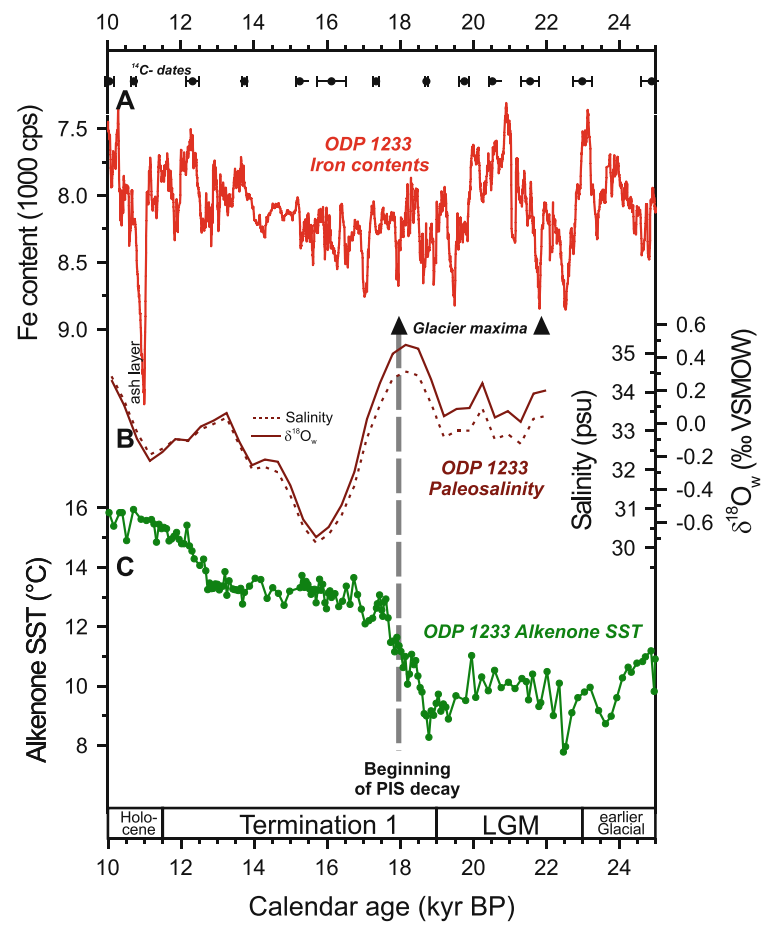




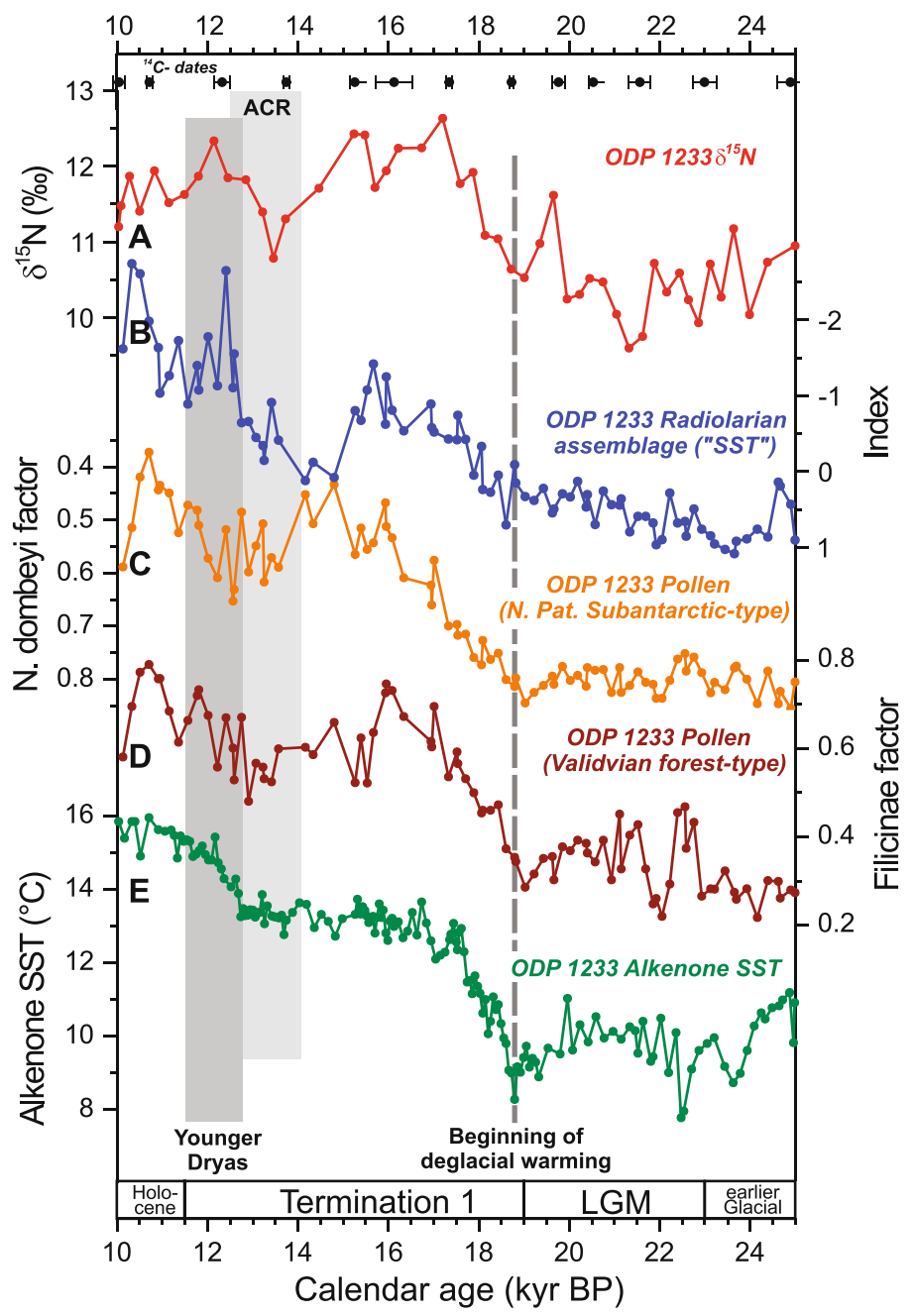

Fig. 6.4 Different paleoenvironmental records from Site 1233 over $\mathrm{T} 1$ and the Last Glacial Maximum plotted on the Lamy et al. (2007) timescale. (A) $\delta^{15} \mathrm{~N}$ record (Martinez et al. 2006). (B) First canonical variates from radiolarian multivariate data sets used as a proxy for SSTs (Pisias et al. 2006). (C) North Patagonian Subantarctic-type pollen (Heusser et al. 2006). (D) Validvian forest-type pollen (Heusser et al. 2006). (E) Alkenone SST record (Lamy et al. 2007)

During the SST minima, the relative abundance of iron in the sediment is increased (Fig. 6.3). However, iron maxima occur several hundred years later than SST minima. These iron maxima have been related to advances of the PIS during the last glacial and the delay interpreted as a lagged response of ice-sheet fluctuations to SST changes in the SE-Pacific (Kaiser et al. 2007; Lamy et al. 2004). Though this pattern is clearer during Marine Isotope Stage 3, a major advance at the eastern 
flank of the PIS at 21.8 kyr BP (Kaplan et al. 2004) fits well to the iron record (Fig. 6.3) (see also 6.4.2). In a recent modeling study of the changes in the Patagonian ice-sheet extent during the Last Glacial Maximum, (Hulton et al. 2002) have shown a good agreement between modelled ice extent and empirical evidence by applying a temperature decrease of $6^{\circ} \mathrm{C}$ relative to present day which is consistent with our alkenone SST record.

The relative glacial SST cooling observed at Site 1233 appears to be a regional feature at least northward up to $33^{\circ} \mathrm{S}$. Glacial SSTs were likewise about $6^{\circ} \mathrm{C}$ cooler than during the Holocene maximum at $\sim 35^{\circ} \mathrm{S}$ (Romero et al. 2006) and $\sim 33^{\circ} \mathrm{S}$ (Kim et al. 2002), whereas a SST record at $\sim 30^{\circ} \mathrm{S}$ suggests a cooling of only $\sim 3.5^{\circ} \mathrm{C}$ (De Pol-Holz et al. 2006). However, compared to the modern SST distribution, gradients appear to be enhanced in the southern Peru-Chile current between $\sim 41^{\circ} \mathrm{S}$ and $\sim 33^{\circ} \mathrm{S}$ consistent with a northward movement of at least $5^{\circ}$ in latitude of the present zone of high SST gradients (Fig. 6.2) linked to the northern margin of the ACC (Kaiser et al. 2005). This is in agreement with modeling results suggesting stronger SST gradients in the mid-latitudes at the Last Glacial Maximum (Shin et al. 2003). This enhanced northward influence of the ACC up to $\sim 33^{\circ} \mathrm{S}$ during the Last Glacial Maximum has also been suggested in paleoproductivity reconstructions along the Chilean coast as it brings the nutrient source closer to the core site resulting in higher biological productivity (Hebbeln et al. 2002; Mohtadi and Hebbeln 2004). A similar conclusion has been derived from the $\delta^{15} \mathrm{~N}$ record at Site 1233 (Fig. 6.4) suggesting that the interplay between nutrient demand in the Subantarcitic Zone and latitudinal shifts of hydrologic fronts controlled both the concentrations and the isotopic signature of the remaining nitrate delivered to the southern Chilean margin (Martinez et al. 2006). However, Thorium-230 normalized biogenic flux calculations based on cores off northern Chile suggest regionally varying Last Glacial Maximum paleoproductivity that was higher at $\sim 27^{\circ} \mathrm{S}$ (Dezileau et al. 2004) and comparable to the Holocene at $\sim 30^{\circ} \mathrm{S}$ (De Pol-Holz et al. 2007). These different results may be related to the enhanced influence of upwelling in the north that could introduce low latitude climate signals through upwelling of water masses of the GUC as suggested e.g. by the $\delta^{15} \mathrm{~N}$ record at Site $1234\left(36^{\circ} \mathrm{S}\right)$ (Robinson et al. 2007).

Extensive analyses of terrigenous sediment input changes along the central and northern Chilean margin suggested a $\sim 5^{\circ}$ latitude equatorward shift of the presentday precipitation gradient resulting in semiarid winter-rain climates at the present southern margin of the Atacama Desert $\left(\sim 27^{\circ} \mathrm{S}\right)$ (Lamy et al. 1998a; Lamy et al. 1999; Lamy et al. 2000; Stuut and Lamy 2004). This northward shift is consistent with terrestrial climate reconstructions (e.g. review by Heusser (2003)) and substantially enhanced the glacial supply of terrigenous material to the ocean in particular off north-central Chile where the terrigenous glacial accumulation doubled (Hebbeln et al. 2007). Taken together, the paleoceanographic and continental paleoclimate reconstructions suggest a $\sim 5^{\circ}$ latitude northward shift of both the oceanographic and the atmospheric circulation systems (northern margin of the ACC and SWW). 


\subsubsection{Link to the High Latitudes}

In previous works, we showed that the complete $\sim 70$-kyr-long alkenone SST record at Site 1233 closely follows millennial-scale temperature fluctuations as observed in Antarctic ice cores (Kaiser et al. 2005; Lamy et al. 2004). There are however comparatively large absolute dating uncertainties of marine sediments in the earlier part of the last glacial due to increasing uncertainties in radiocarbon dating and calendar year conversion, whereas large amplitude methane fluctuations allow a detailed inter-correlation of Greenland and Antarctic ice-cores (Blunier and Brook 2001; EPICA Community Members 2006). Nevertheless, this methane-based correlation reveals ambiguities over the interval of the Last Glacial Maximum and beginning of Termination 1 where radiocarbon dating errors are relatively small. Consequently, the comparison of our SST data-set to Antarctic ice-core records reveals some offsets around the Last Glacial Maximum (Fig. 6.5). For example, the SST minimum close to $22.5 \mathrm{kyr}$ BP may well correspond to the temperature minimum at $\sim 21.5$ kyr BP in the Byrd record (Pacific Sector of Antarctica, Fig. 6.1). As well, the new record from Dronning Maund Land (EPICA Community Members 2006) (DML; Atlantic Sector, Fig. 6.1) shows a millennial-scale warming between 23.5 and 24.5 kyr BP (Antarctic Isotope Maximum 2) that occurs 500 years later than a warming shown in the SST data (see 6.4.2. and Lamy et al. (2007) for further discussion of the delay in the Antarctic records).

\subsubsection{Link to the Tropics}

Based on coupled ocean-atmosphere models, Shin et al. (2003) have proposed that the upper ocean circulation in the southern mid- and high-latitudes plays a key role in explaining tropical cooling at the Last Glacial Maximum. This connection could be explained by a transmission of South Pacific SST cooling through the surface ocean via the Eastern Boundary Current system (PCC) and through intermediate water masses towards the tropics (Clark et al. 2004). Such a link has been proposed based on $\mathrm{Mg} / \mathrm{Ca} \mathrm{SST}$ reconstruction near the equator (Lea et al. 2006; Lea et al. 2000) and on the presence of high southern latitude foraminifera species even north of the equator suggesting an intensification of the Peru-Chile Current during the Last Glacial Maximum (e.g., Feldberg and Mix 2003; Martinez et al. 2003).

A direct comparison of our Site 1233 SST record to tropical SST reconstruction is difficult as the records have very different time resolutions and age models. However, some similarities are apparent in particular regarding the comparison to the high resolution eastern tropical Pacific $\mathrm{Mg} / \mathrm{Ca} \mathrm{SST}$ record that reveals some similar features also on millennial time-scales (Lea et al. 2006) (Fig. 6.7). Kaiser et al. (2005) performed a time-slice analysis in order to compare SST gradients along the PCC from $41^{\circ} \mathrm{S}$ (Site 1233) to just north of the equator $\left(2^{\circ} \mathrm{N}\right)$. During the Last Glacial Maximum, the overall mid-latitude-to-equator gradient $\left(2^{\circ} \mathrm{N}-41^{\circ} \mathrm{S}\right)$ was $\sim 3^{\circ} \mathrm{C}$ higher than today. This increase in meridional SST gradients during the Last Glacial Maximum is mainly derived from a relatively strong cooling in the southern and central part of the PCC $\left(41-17^{\circ} \mathrm{S}\right)$, with particularly enhanced gradients 


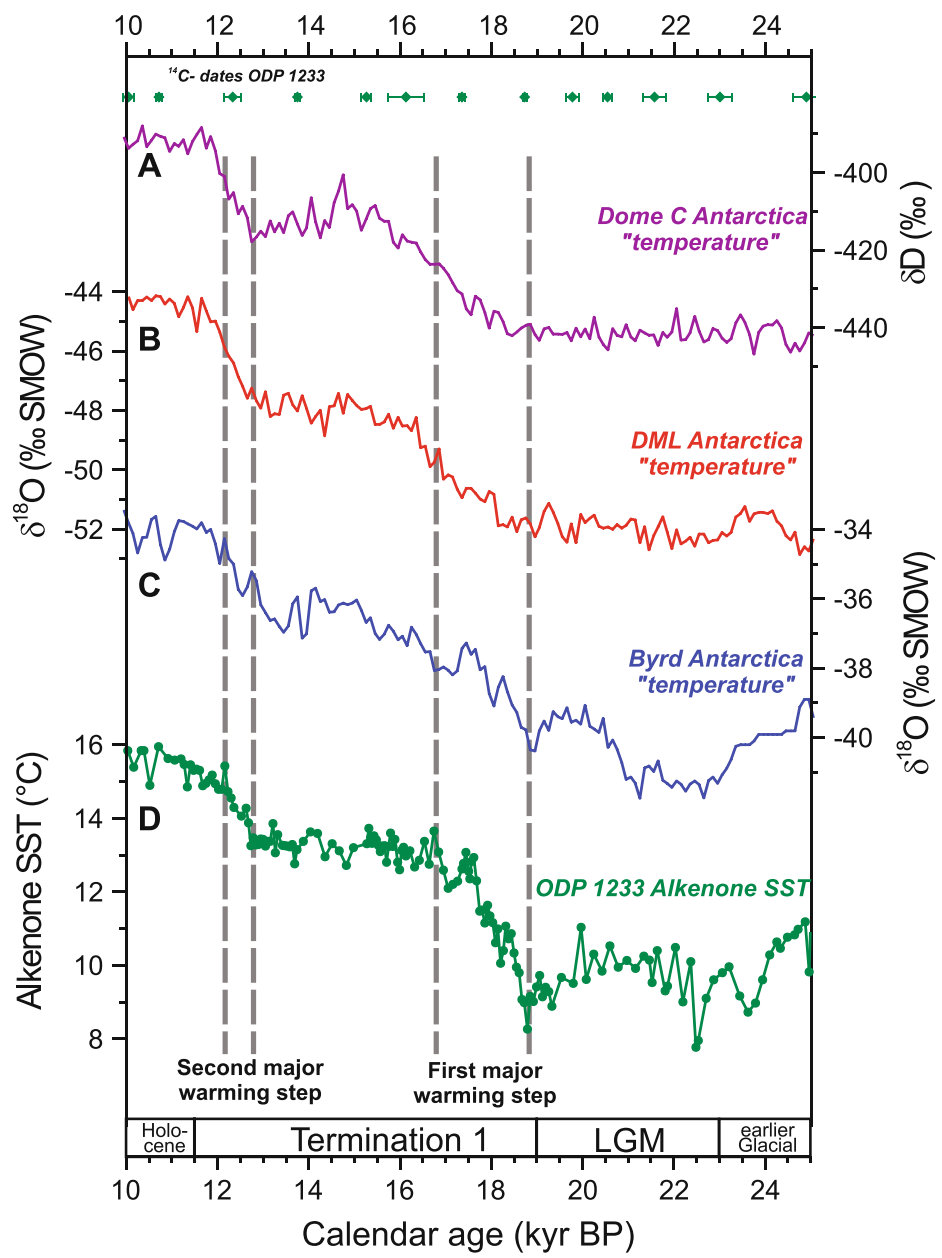

Fig. 6.5 Site 1233 SST record compared to different Antarctic temperature proxy records over the Last Glacial Maximum and T1. (A) Deuterium record from the Dome C ice-core (EPICA Community Members, 2004) (continental site in eastern Antarctica). (B) Oxygen isotope record from the Dronning Maud Land (DML) ice-core (EPICA Community Members, 2006) (coastal site, Atlantic sector). (C) Oxygen isotope record from the Byrd ice-core (Blunier and Brook 2001) (coastal site, Pacific sector). All ice-core records are plotted on the GICC05 displaying 100-years averages. (D) Alkenone SST record from Site 1233 with radiocarbon datings (top of panel A)

in the southernmost part between $\sim 33^{\circ} \mathrm{S}$ and $41^{\circ} \mathrm{S}$ consistent with a ACC/SWW northward shift of $\sim 5^{\circ}$ in latitude in comparison to the present day (see above). In addition, a northward displacement of the SWW (or their northern boundary), as implied by Kaiser et al. (2005) results, would be in agreement with the proposed northward shift of the eastern Pacific STH at the Last Glacial Maximum (Andreasen and Ravelo 1997; Mohtadi and Hebbeln 2004). 


\subsubsection{Termination 1}

The termination of the last ice age (Termination 1; T1) is the last major climate transition of the Earthś recent geological history and is thus crucial for our understanding of modern climate processes and the validation of climate models. Though $\mathrm{T} 1$ is very well studied involving numerous proxy records from both marine and terrestrial archives (e.g., Alley and Clark 1999; Clark et al. 1999; Clark et al. 2004; Rinterknecht et al. 2006) as well as modelling studies (e.g., Knorr and Lohmann 2003; Weaver et al. 2003), there are still a number of open questions regarding for example the exact timing and the mechanisms involved in the initiation of deglaciation and the subsequent interhemispheric pattern of the warming. The present picture of climate pattern during T1 is thus largely focussed on high latitude records in particular from Greenland and Antarctic ice-cores that have been synchronised by correlating globally recordable methane fluctuations (e.g., Blunier and Brook 2001; EPICA Community Members 2006; Morgan et al. 2002). However, this correlation reveals ambiguities over the interval of the early deglacial warming in the Southern Hemisphere making the analysis of interhemispheric climate pattern over this important interval more difficult. Site 1233 improves our understanding of the sequence of events over the last termination as it provides exceptional time-resolution and dating accuracy over T1 (Lamy et al. 2007).

\subsubsection{Regional Aspects}

The alkenone SST record of Site 1233 reveals a beginning of deglacial warming at $\sim 18.8$ kyr BP with a $\sim 2$-kyr-long increase of nearly $5^{\circ} \mathrm{C}$ until $\sim 16.7 \mathrm{kyr}$ BP (Figs. 6.4and 6.5). Thereafter, temperatures remain comparatively stable until the beginning of a second warming step of $\sim 2^{\circ} \mathrm{C}$ between $\sim 12.7$ and $\sim 12.1 \mathrm{kyr}$ BP. This pattern is consistent with independent SST estimates from Site 1233 based on radiolarian assemblages (Pisias et al. 2006) (Fig. 6.4), that show however a cooling event between $\sim 13$ and 15 kyr BP. Furthermore, the first warming step coincides with a major shift in the $\delta^{15} \mathrm{~N}$ record from Site 1233 (Fig. 6.4) that has been explained by a southward shift of fronts in the Southern Ocean (Martinez et al. 2006).

Melting of the PIS onshore started significantly later than the initial SST rise as documented by two well-dated glacier maxima in the Chilean Lake District between $\sim 18.0$ to 17.7 kyr B.P. (Denton et al. 1999a) that occurred while SSTs were already increasing rapidly for $\sim 1,000$ years (Fig. 6.3). Additional support for a delayed ice sheet response comes from our reconstruction of paleosalinity over T1 (Lamy et al. 2004) (Fig. 6.3). The substantial decrease in salinities from $\sim 17.8$ to $15.8 \mathrm{kyr}$ B.P. suggests that the PIS was wasting rapidly after the last glacier maxima inferred from terrestrial studies (Denton et al. 1999b). During this period, Fe contents remain high and most likely reflect strong fluvial erosion of the rapidly exposing glacial deposits. Thereafter Fe contents decrease towards the Holocene when they become rainfall-controlled (Lamy et al. 2001). These observations suggest that a substantial time-lag occurs between climate forcing and the PIS response - assuming that the atmospheric system responds roughly synchronously to changes in SSTs which is 
reasonable for the extremely maritime climate conditions in southern Chile. The changing time-lag along the record suggests a possible relationship to ice sheet size (see for further details Lamy et al., 2004and Kaiser et al., 2007). The largest lag is observed for the decay of ice after its maximum extent before the deglaciation (Lamy et al. 2004).

Though the general magnitude of $\sim 6-7^{\circ} \mathrm{C}$ SST warming over T1 is similar to results obtained from land (e.g., reviews by Denton et al. 1999a; Heusser and Heusser 2006), there are differences in the timing between the terrestrial datasets and our marine record. Pollen records from the Lake District and Chiloe Island (Taiquemo) suggest a beginning of warming at $\sim 17.5 \mathrm{kyr}$ BP, i.e. more than 1,000 years later than the initial SST warming. We originally interpreted this lag as being related to the response time of the PIS and the surrounding ecosystems (Lamy et al. 2004). However, there are now pollen records available from Site 1233 (Heusser et al. 2006) that suggest that the beginning of deglacial changes in the pollen records was basically in phase with the initial SST rise (Fig. 6.4). These new data show that pollen characteristic for the North Patagonian Subantarctic vegetation types substantially decreased after $\sim 19$ kyr. whereas Valdivian Forest type pollen (primarily ferns) increase (Fig. 6.4). The reasons for the offset between the marine and continental pollen records remain unclear. One possibility is that reservoir ages at the beginning of T1 were substantially higher than present day values that we assumed for Site 1233. As discussed in detail in our previous publications (Kaiser et al. 2005; Lamy et al. 2004), we assume no regional deviation from the global reservoir effect of $\sim 400$ years because of the presence of an early Holocene volcanic ash layer at Site 1233 (that has been likewise dated on land) and the position of our site significantly south of the Chilean upwelling zone (Strub et al. 1998) and north of the southern polar front where higher reservoir ages may be expected. Furthermore, our paleosalinity reconstruction fits very well to the land-based evidence for the timing of the rapid PIS decay after $\sim 17.8 \mathrm{kyr}$ BP, that can be taken as a further evidence that the Site 1233 age-model is correct (Fig. 6.3). On the other hand, local conditions may be over-represented at terrestrial sites close to the margins of the PIS (at least before the rapid decay of the ice-sheet) or the records may be incomplete whereas the marine pollen record is reflecting a more integrated regional signal including areas that are not directly affected by the presence of the large ice-sheet.

Another important issue regarding the comparison of our marine to regional terrestrial records are the climate pattern during later Termination 1. Pollen records in the Lake District and on Chiloé Island have been interpreted in terms of a cooling during the Northern Hemisphere Younger Dryas (YD) (e.g., Denton et al. 1999a; Moreno et al. 2001) whereas the alkenone and radiolaria-based SST reconstructions from Site 1233 reveal a clear warming during the YD (Fig. 6.3). However, it has been recently suggested that the deglacial cold reversal in NW Patagonia started earlier (at 14.7-13.4 kyr BP.), and that the YD interval is rather characterized by fire disturbance (Hajdas et al. 2003; Moreno 2004) that may not necessarily imply cooling. In addition, other paleoenvironmental reconstructions in southern Chile $\left(\sim 40^{\circ} \mathrm{S}\right.$ to $48^{\circ} \mathrm{S}$ ) based on pollen, glacial morphology, and beetle assemblages did not find evidence of a cooling during the YD epoch either (Ashworth and Hoganson 1993; 
Bennett et al. 2000; Glasser et al. 2004). In the lower latitudes, two SST records located at $\sim 35^{\circ} \mathrm{S}$ (Romero et al. 2006) and $\sim 30^{\circ} \mathrm{S}$ (De Pol-Holz et al. 2006) present a very similar pattern to ODP Site 1233 with a $1-2^{\circ} \mathrm{C}$ warming during the YD. Only one SST record at $\sim 33^{\circ} \mathrm{S}$ shows a cooling over this time-interval (Kim et al. 2002).

The different records from Site 1233 partly suggest a cold reversal between $\sim 14.5$ and $12.5 \mathrm{kyr}$ BP, synchronously to the Antarctic Cold Reversal (ACR; 14-12.5 kyr BP; Jouzel et al. 1995). Whereas the alkenone-based SST record shows rather a plateau, the radiolarian assemblage and the pollen records imply a cooling. The $\delta^{15} \mathrm{~N}$ record suggests a slight northward shift of the Southern Ocean fronts (Fig. 6.4). Recent studies based on glaciers fluctuations in southernmost Chile $\left(46-55^{\circ} \mathrm{S}\right)$ evidence a glacial re-advance during this time-interval (see for a review Sugden et al. 2005). Taken together, these results imply a slight northward movement of the atmospheric and oceanographic systems in the southeast Pacific during the ACR.

\subsubsection{Link to the High Latitudes}

A comparison of our SST record to different Antarctic ice-core records suggests a general correspondence in the major temperature trends, particularly the two-step warming over T1 (Fig. 6.5). As in our SST record, in the Pacific Sector of Antarctica, (Byrd ice-core (Blunier and Brook 2001), deglacial warming initiated shortly after 19 kyr BP whereas the new record from Dronning Maund Land (EPICA Community Members 2006) (DML; Atlantic Sector; Fig. 6.5) shows a 700 years delayed initiation of deglacial warming. In the Dome $\mathrm{C}$ record (EPICA Community Members 2004) (continental site, Fig. 6.5), the initial warming starts at about the same time as in the DML record. In general, the deglacial warming as documented in Antarctic ice-cores is substantially more gradual than observed in our SST record where most of the initial warming occurs over a time-interval of only $\sim 1,200$ years $(\sim 18.8-17.6$ kyr BP $)$.

Millennial-scale temperature changes in Antarctica over the last glacial may be consistently explained by the bipolar seesaw concept that suggests an out-of-phase millennial-scale climate pattern between the Northern and Southern Hemisphere during the last glacial (e.g., Stocker 1998). The concept was later extended by including a time constant that describes the thermal storage effect of the Southern Ocean and explains why glacial Antarctic and Greenland temperatures are not strictly anti-correlated but are rather characterised by a lead-lag relationship (Knutti et al. 2004; Siddall et al. 2006; Stocker and Johnsen 2003). The timing of both the initial and the second warming step (12.7-12.1 kyr BP) in the Site 1233 alkenone SST record suggests that the SST response in the mid-latitude SE-Pacific occurred quasi instantaneous to the starting slowdown of the Atlantic Meridional Overturning Circulation (AMOC) (Fig. 6.6). The conceptual model of Stocker and Johnsen (2003) shows such strict antiphase behaviour for the South Atlantic. However, the occurrence of an "immediate" and high amplitude response in our SST record requires a rapid transfer of the Atlantic signal to the SE-Pacific without involving the thermal inertia of the Southern Ocean that contributed to the substantially more 
gradual and partly delayed (in case of the DML and Dome C records) deglacial temperature rise seen in Antarctic ice-cores. The most plausible mechanism for this rapid transfer is a seesaw induced change of the coupled ocean-atmosphere system of the ACC and the SWW as indicated by modelling studies (Timmermann et al. 2005). The SST response to a weakening of the AMOC in these and other model simulations (e.g., Knutti et al. 2004; Schmittner et al. 2002) is however much smaller than the initial warming observed at Site 1233 (Fig. 6.6). Apart from the pronounced regional sensitivity of Site 1233 due to strong regional SST gradients, more global forcings such as changes in $\mathrm{CO}_{2}$ and atmospheric dust explain an important fraction of the deglacial SST rise in the SE-Pacific (Fig. 6.6). In addition, it has been

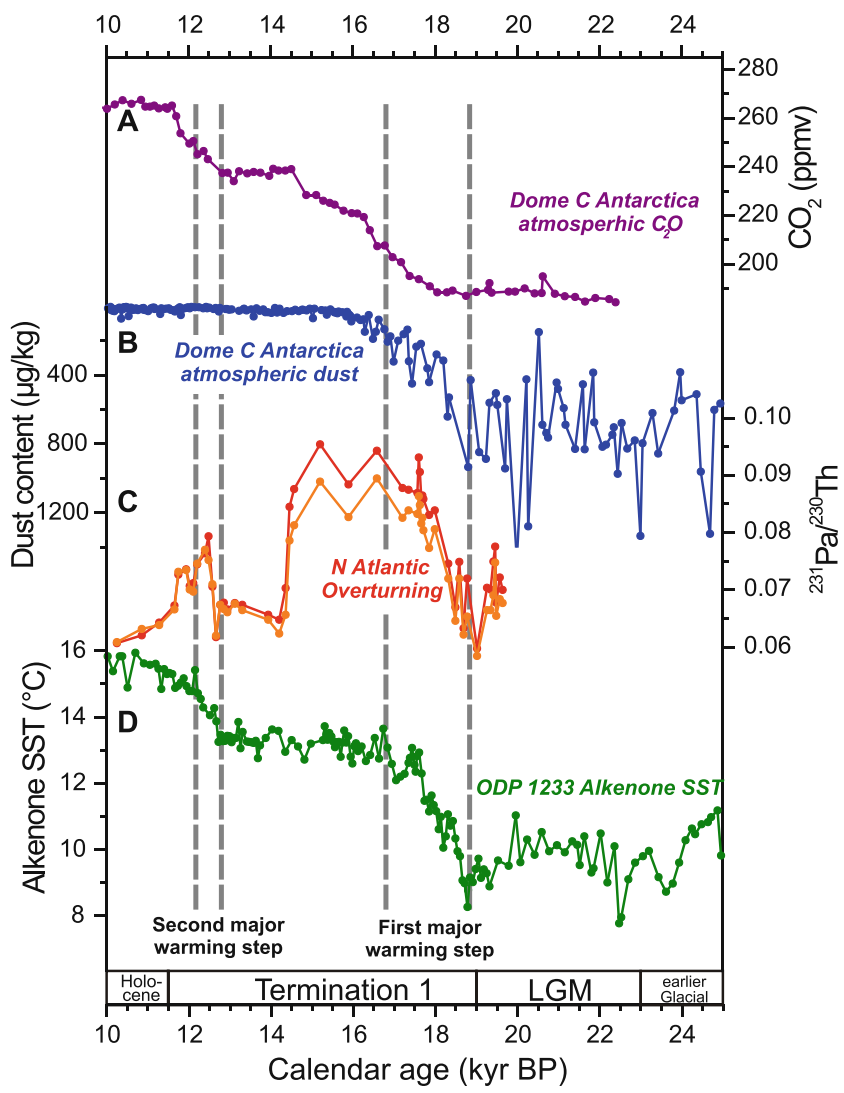

Fig. 6.6 Comparison of Site 1233 SST record to atmospheric dust and $\mathrm{CO}_{2}$ records based on the Antarctic Dome $\mathrm{C}$ ice core and to a North Atlantic record of past changes in the AMOC over T1. (A) $\mathrm{CO}_{2}$ record from the Dome $\mathrm{C}$ ice-core (Monnin et al. 2001) (revised time-scale as in Lamy et al. (2007)). (B) Atmospheric dust content record from the Dome C ice-core (Delmonte et al. 2002) (revised time-scale as in Lamy et al. (2007)). (C) ${ }^{231} \mathrm{~Pa} /{ }^{230} \mathrm{Th}$ record from a subtropical North Atlantic sediment core taken as a proxy for the strength of the AMOC (McManus et al. 2004). (D) Alkenone SST record from Site 1233 (Lamy et al. 2007) 
recently suggested that increasing austral-spring insolation combined with sea-ice albedo feedbacks may be responsible for an early SH warming between 19 and 17 kyr BP (Stott et al. 2007)

Assuming that the Site 1233 SST record largely reflects shifts of the coupled ACC/SWW system, the concurrence to atmospheric $\mathrm{CO}_{2}$ changes over T1 is consistent with the previously suggested important role of such latitudinal shifts in controlling atmospheric $\mathrm{CO}_{2}$ contents (Ninnemann and Charles 1997; Toggweiler et al. 2006). Based on a general circulation model, Toggweiler et al. (2006) showed that equatorward shifted SWW during the glacial allowed more respired $\mathrm{CO}_{2}$ to accumulate in the deep ocean. During glacial terminations, the southward moving SWW reduced polar stratification and enhanced upwelling of deepwater masses around Antarctica that would then have released large amounts of the stored $\mathrm{CO}_{2}$ to the atmosphere (for details see Lamy et al. 2007).

\subsubsection{Link to the Tropics}

The large unknown in most paleoclimate scenarios for Termination 1 is the role of the tropics where in particular tropical Pacific SST changes have large impacts on the hydrological cycle and changes in greenhouse gases (Clark et al. 2004; Palmer and Pearson 2003). An increasing number of high resolution records from the tropics have recently become available (e.g., Lea et al. 2006; Visser et al. 2003). As deglacial warming in some of these records occurred largely in phase with the $\mathrm{CO}_{2}$ increase as observed in Antarctic ice-cores, they have been interpreted in support for a tropical "trigger" for the deglaciation (Visser et al. 2003). Though a tropical "trigger" (such as changes in ENSO) for the initiation of the last deglaciation can not be strictly excluded, we note that most of the available data could be explained by an initiation in the Northern Hemisphere and associated bipolar seesaw effects (see Lamy et al. 2007 for details). A SST record from the Indo-Pacific Warm Pool shows for example the start of deglacial warming, within dating uncertainties, quasi synchronous with our Southeast Pacific record (Fig. 6.7) but changes are more gradual and the total SST change over T1 is much smaller (Visser et al. 2003). However, very recently Stott et al. (2007) evidenced that during the early deglaciation the deep water originating from the Southern Ocean (the upper Pacific Deep Water) warmed about 1,000 years before the surface water of the western tropical Pacific. Our southeast Pacific two-step warming structure with an intervening "plateau" is visible in the eastern tropical Pacific (Lea et al. 2006) (Fig. 6.7). These similarities may well be explained by a transmission of South Pacific SST warming through the surface ocean via the Eastern Boundary Current system and through intermediate water masses towards the tropics (Clark et al. 2004). In these scenarios, the tropics did not initiate the global warming over T1, but they probably played an important role for a number of positive feedbacks (through affecting e.g. atmospheric water vapour and $\mathrm{CO}_{2}$ content) finally leading out of the last glacial period. 


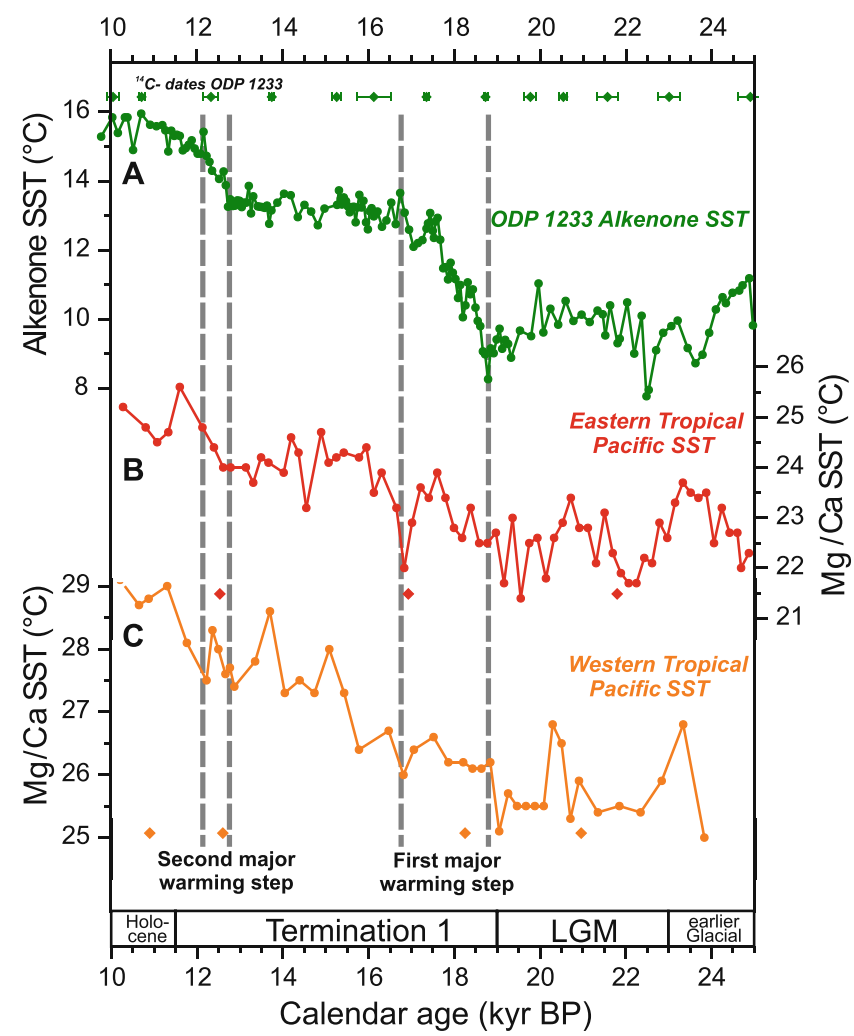

Fig. 6.7 Comparison of Site 1233 SST record to tropical Pacific SST records over T1 (see Fig. 6.1 for site locations). (A) Alkenone SST record from Site 1233 with radiocarbon datings (Lamy et al. 2007). (B) $\mathrm{Mg} / \mathrm{Ca}$ SST record from the eastern tropical Pacific (Lea et al. 2006) with radiocarbon datings. (C) Mg/Ca SST record from the Indo-Pacific Warm Pool (Visser et al. 2003) with radiocarbon datings

\subsubsection{Holocene}

\subsubsection{Regional Aspects}

After the second major warming step of $\mathrm{T} 1$ from $\sim 12.7$ to $\sim 12.1 \mathrm{kyr} \mathrm{BP}$, the alkenone-based SST record from Site 1233 shows maximum warm conditions in the early Holocene ( 12-9 kyr BP; Fig. 6.8) (Kaiser et al. 2005). SSTs during this interval were generally between $\sim 15$ and $16^{\circ} \mathrm{C}$, i.e. $\sim 1-2^{\circ} \mathrm{C}$ above modern values. Thereafter, temperatures gradually decline reaching the modern SST $\left(\sim 14^{\circ} \mathrm{C}\right)$ in the Late Holocene (Fig. 6.8). The early Holocene optimum was not documented in the higher resolution earlier SST record based on core GeoB 3313-1 (Lamy et al. 2002) that only covers the past $\sim 8 \mathrm{kyr}$ (Fig. 6.9). In this record, a secondary middle Holocene warming is observed around $5.5 \mathrm{kyr}$ BP with SSTs generally declining 


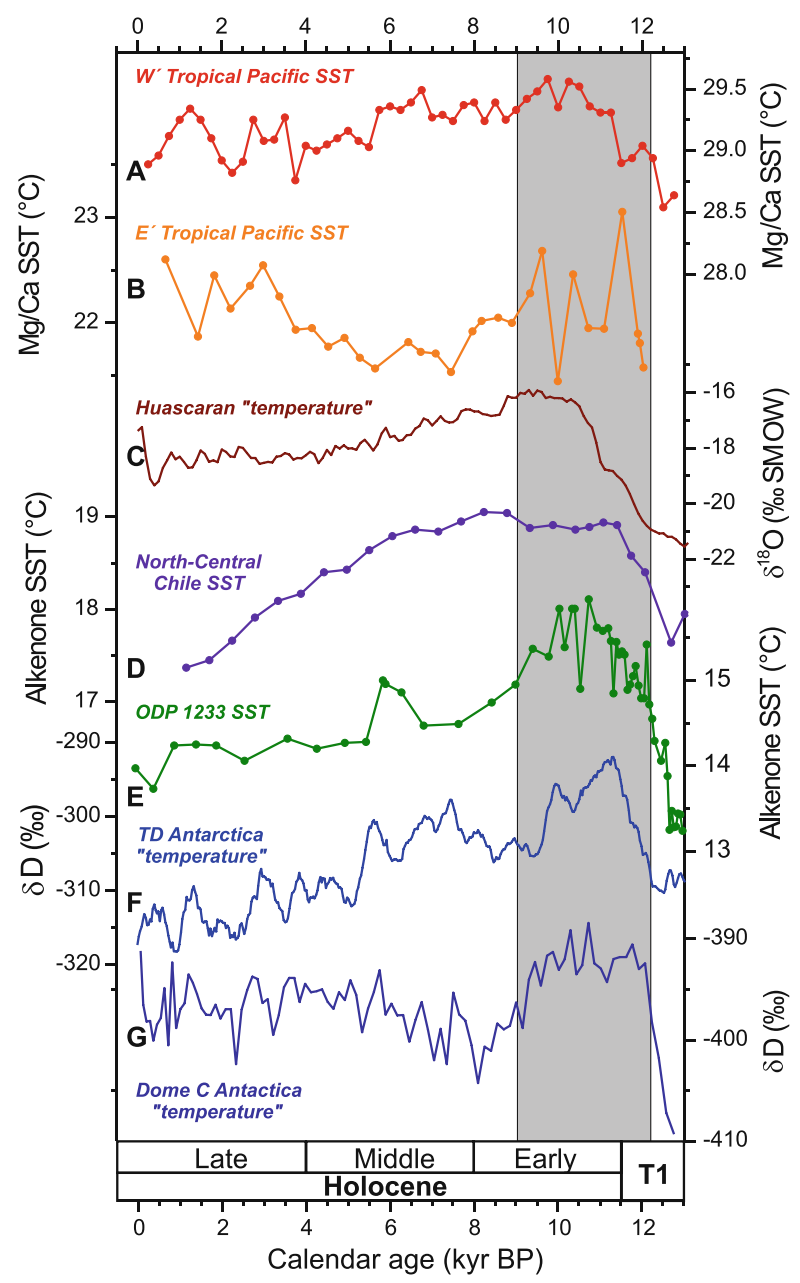

Fig. 6.8 Holocene Site 1233 SST record compared to Antarctic and South American ice core data and (sub)tropical marine data-sets (see Fig. 6.1 for site locations). Gray bar marks early Holocene maximum warm phase as defined at ODP Site 1233 (Kaiser et al. 2005). (A) SST record from the western Pacific Warm Pool (stacked data from several cores as in (Stott et al. 2004)). (B) SST record from the eastern Pacific cold tongue (Koutavas et al. 2002). (C) Huascaran $\delta^{18} \mathrm{O}$ record as a proxy for temperature changes in tropical South America (Thompson et al., 1995). (D) SST record from core GeoB 7139-2 off north-central Chile (De Pol-Holz et al. 2006). (E) SST record from ODP Site 1233 (Kaiser et al. 2005; Lamy et al. 2007). (F) $\delta$ D record from the Taylor Dome ice core as a proxy for western Antarctic temperature (Steig et al. 1998). (G) $\delta$ D record from the Taylor Dome ice core as a proxy for eastern Antarctic temperature (EPICA Community Members 2004)

afterward towards the late Holocene as in the comparatively low resolution SST record from Site 1233 (Fig. 6.8).

The general middle and late Holocene SST cooling off southern Chile is paralleled by similar trends in continental rainfall and paleosalinity depicted in core 
Fig. 6.9 Paleoceanographic and continental paleoclimate records from core $\mathrm{GeoB}$ 3313-1 off southern Chile covering the middle and late Holocene. Bold lines are 2000-yr moving averages (after Lamy et al. 2002). (A) Iron contents interpreted as a proxy for rainfall and the position of the Southern Westerlies (high iron contents imply increased contribution of iron-rich volcanic Andean source rocks and decreased supply of iron-poor Coastal Range source rocks indicating decreased rainfall (Lamy et al. 2001)) (B) SST record tracing the advection of subpolar water by the ACC. (C) Paleosalinity (SSS) reconstruction (5-point moving average) as a proxy for fresh-water input in the Chilean Fjord region. (D) Corg contents and (E) biogenic opal contents are taken as proxies for paleoproductivity

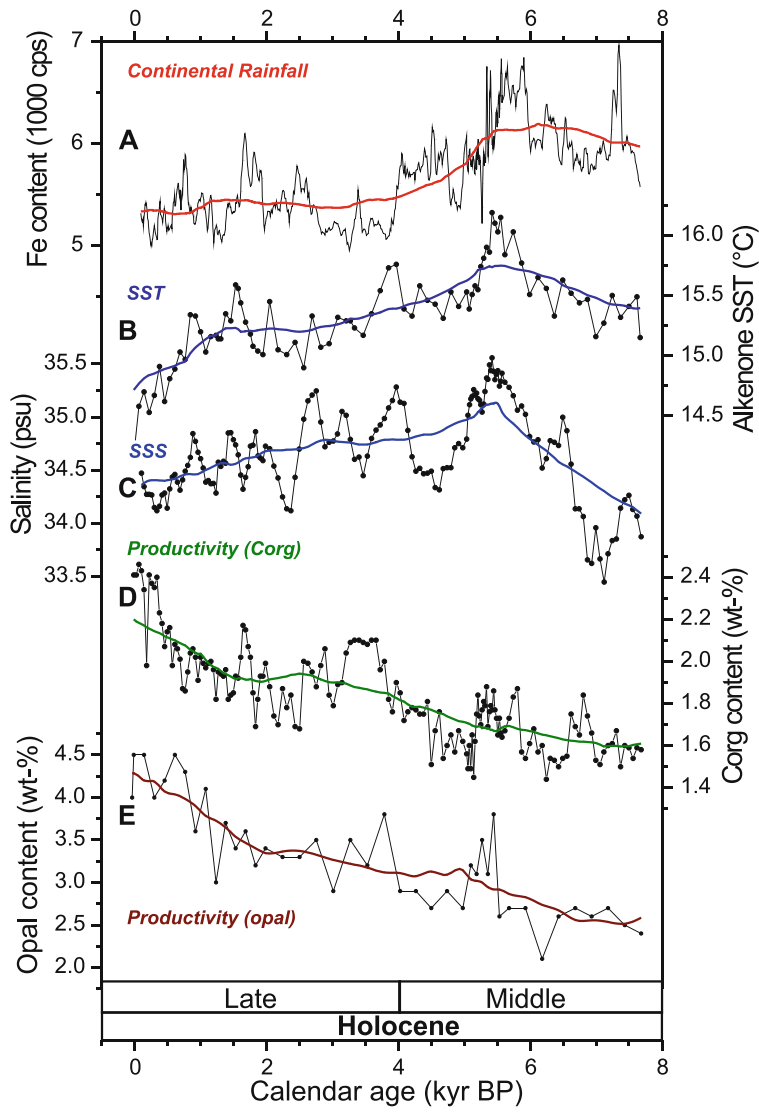

GeoB 3313-1 (Lamy et al. 2001) (Fig. 6.9). These data show generally drier conditions during the early and middle Holocene and increased precipitation during the late Holocene consistent with regional terrestrial records from Chiloé Island (e.g., Abarzúa et al. 2004) and central Chile (e.g., Jenny et al. 2002; Villagrán and Varela 1990), as well as marine records located further north (Lamy et al. 1999). Similarly, marine productivity (based on organic carbon and opal contents) along the southern part of the PCC was lower during the early and middle Holocene (Fig. 6.9) and increased afterwards, interpreted in terms of latitudinal shifts of the ACC as the main source for nutrients in the PCC system combined with higher input of terrestrial micronutrients (Hebbeln et al. 2002; Lamy et al. 2002). Though paleoproductivity estimates based on contents of biogenic components may be substantially affected by dilution and preservation effects, rather constant Holocene sedimentation-rates and little diagenetic overprint of the organic matter over this time interval (Mix et al. 2003) suggest that they are reliable in this case. Taken together, these long term Holocene trends suggest, as in the glacial, a close coupling 
of the main oceanographic (ACC) and atmospheric (SWW) circulation members of the southeast Pacific

The pattern of shorter-term variability on millennial and centennial time-scales is more complex (Lamy et al. 2002). Since it is assumed that past latitudinal shifts of the SWW were likewise connected to latitudinal shifts of the ACC, a southward displacement of the SWW during the Holocene should be associated with higher SSTs and lower productivity comparable to the long-term trend. However, many of the multi-centennial to millennial-scale variations in paleotemperatures and - salinities do not exactly match the reconstructed shifts of the SWW in particular after $\sim 5$ kyr B.P (Figs. 6.9and 6.10). The paleoproductivity records from core GeoB 3313-1 (Fig. 6.10) exhibit two century-scale excursions to higher values between 5.5 and 5 kyr BP and shortly after 4 kyr BP which do not exactly coincide with SST minima. Instead, they occur during cooling phases shortly after the two most significant increases in rainfall in the continental hinterland (Fig. 6.10). The Fe record (Fig. 6.10) indicates that these rainfall augmentations terminated the less humid phase of the middle Holocene in southern Chile, pointing to a significant contribution of continent-derived micronutrients which resulted in an increase of marine productivity off southern Chile for several centuries (Lamy et al. 2002) consistent with similar results based on orbital-scale productivity changes in relation to terrigenous micronutrients input off northern Chile (Dezileau et al. 2004)

\subsubsection{Link to the High Latitudes}

The early Holocene optimum depicted at Site 1233 coincides with warm conditions recorded both in the Eastern Antarctic ice cores Dome C and DML (Masson-Delmotte et al. 2004; EPICA Community Members 2004; EPICA Community Members 2006) as well as the Western Antarctic Taylor Dome (Steig et al. 1998), where the maximum warming appears to be restricted to a shorter interval, however (Fig. 6.8). Long-term trends in the ice core records partly deviate as large-scale Antarctic cooling during the Holocene is locally compensated by a decrease of a few tens of metres in the icesheet elevation, in response to the ice-sheet dynamics (Masson-Delmotte et al. 2004). However, there appears to be a consistent multi-centennial-scale temperature pattern in Antarctica over the Holocene (Masson-Delmotte et al. 2004; Masson et al. 2000) with a cyclicity of $\sim 830$ years that partly correlates to SST changes as recorded in core GeoB 3313-1 off southern Chile (Fig. 6.10).

\subsubsection{Link to the Tropics}

A SST record off northern mid-latitude Chile $\left(30^{\circ} \mathrm{S}\right.$; Fig. 6.8) (De Pol-Holz et al. 2006) displays a slightly delayed optimum warming that lasted longer, i.e. into the middle Holocene, a pattern that likewise appears in the tropical South American ice core record recovered at the Nevado de Huascaran (Fig. 6.8) (Thompson et al. 1995). North of $30^{\circ} \mathrm{S}$ there are very few sedimentary records along the Chilean margin that cover the Holocene with a reasonable resolution because terrestrial sediment input is minimal off the hyper-arid Atacama Desert. One of the few records 


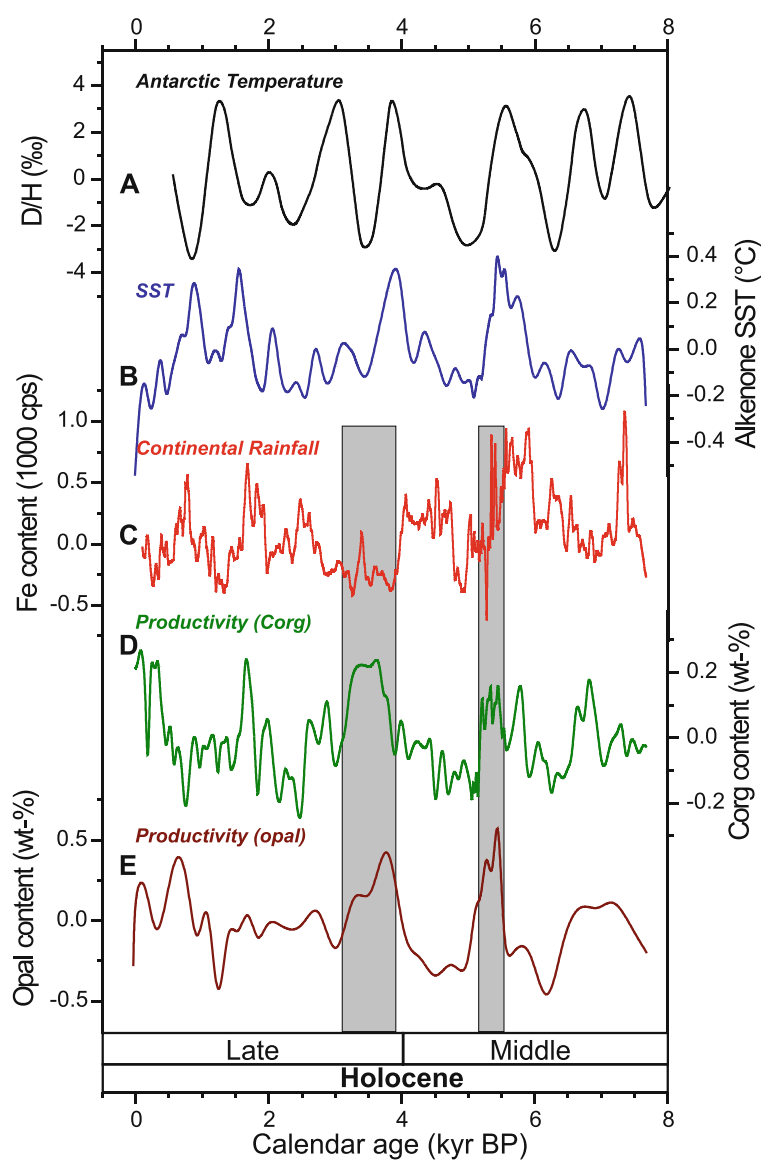

Fig. 6.10 Paleoceanographic and continental paleoclimate records from core GeoB 3313-1 off southern Chile focusing on the millennial to centennial-scale variations compared to Antarctic icecore records. Data-sets have been detrended by subtracting the long-term trends shown in Fig. 6.5 (after Lamy et al. 2002). (A) Short-term variability in Antarctic temperature shown as the first component of an empirical orthogonal function (EOF) analysis calculated from isotopic records from the Ross sea sector (Byrd and Taylor Dome sites) (Masson et al. 2000). (B) SST record off Chile showing a significant positive correlation $(r=0.57, n=57$; significant on the $99.9 \%$ level after applying a 100 year time-resolution interpolation) to Antarctic temperatures until ca. 2000 B.P. (C) Iron contents of core GeoB 3313-1 indicating rainfall and the position of the SWW. Paleoproductivity proxies (D) Corg content and (E) biogenic opal content. Vertical gray bars mark time intervals of century scale increases in paleoproductivity as discussed in the text

comes from core GeoB 7112, located on the continental slope at $\sim 24^{\circ} \mathrm{S}$ (Mohtadi et al. 2004). Though there is no direct SST proxy record available, several proxy records for marine productivity changes suggest that upwelling intensity was substantially reduced and the advection of warmer subtropical surface was enhanced during the early and middle Holocene. After $\sim 5 \mathrm{kyr}$ BP, the pattern reverses, i.e. upwelling became slightly stronger and surface waters were colder, consistent with 
the SST record core GeoB 7139 at $\sim 30^{\circ} \mathrm{S}$ (Fig. 6.8). As observed in most of the Chilean records further south, the variability in the records appears to be higher during the late Holocene, a pattern that may relate to more frequent and stronger El Niño events.

In the tropical Pacific, Holocene paleoceanographic records have been derived from sediment records of the Western Pacific Warm Pool and the Eastern Pacific Cold Tongue (Koutavas et al. 2002; Stott et al. 2004). These are both regions that today are particularly sensitive to SST changes connected to ENSO. While the western Pacific records display a slight $\left(\sim 0.5^{\circ} \mathrm{C}\right)$ cooling over the past $10 \mathrm{kyr}$, the SST record from the cold tongue reveals a broad middle Holocene cooling on the order of $1{ }^{\circ} \mathrm{C}$ (Fig. 6.8). These data suggest enhanced zonal SST gradients during the middle Holocene that decrease after $\sim 5 \mathrm{kyr}$, a pattern that would suggest a mean La Niña-like state of ENSO during the middle Holocene and a larger impact of El Niño events during the later part, broadly consistent with marine records from the Peruvian shelf (Rein et al. 2005) and terrestrial data from Equador (Moy et al. 2002). In addition, the western Pacific records show a long-term decrease in salinity over the course of the Holocene that may imply a general change in tropical hydrology, possibly related to a northward shift of the Intertropical Convergence Zone (Stott et al. 2004).

Lamy et al. (2001) suggested that changes in the tropical climate system on multicentennial to millennial-scales largely control rainfall variability in southern Chile as documented in core GeoB 3313-1 by a dominant $~ 900$ years cycle that is likewise found in the Bolivian Sajama ice core record (Thompson et al. 1998). These variations most likely involve changes in the strength of the Hadley Cell over the Southeast Pacific and adjacent South America. On the other hand, the correlation to climate conditions in Antarctica on millennial and multicentennial time-scales reveals a major phase shift at $\sim 4$ kyr BP that roughly coincides with the onset of modern ENSO. A shift at the transition from the middle to the late Holocene is also evident in the comparison of the short-term rainfall fluctuations to surface ocean changes (Fig. 6.9) (Lamy et al. 2002). This suggests a mismatch between millennial and multi-centennial-scale variability in atmospheric (SWW) and oceanographic (southern PCC and ACC) circulation patterns during the late Holocene (Fig. 6.10). The proposed explanation is that paleotemperatures in the southern PCC during the late Holocene have probably not been affected by changes in ENSO (Lamy et al. 2002). Modern ENSO-related SST anomalies only reach south to $33^{\circ}-36^{\circ} \mathrm{S}$ wheras meteorological studies suggest a strong effect of ENSO on rainfall anomalies both in central and southern Chile (Montecinos and Aceituno 2003).

\section{References}

Abarzúa AM, Villagrán C, Moreno PI (2004) Deglacial and postglacial climate history in eastcentral Isla Grande de Chiloe, southern Chile ( $\left(3^{\circ} \mathrm{S}\right)$. Quat Res 62:49-59

Alley RB, Clark PU (1999) The deglaciation of the Northern Hemisphere. Annu. Rev. Earth Planet Sci 27:149-182 
Andreasen DJ, Ravelo AC (1997) Tropical Pacific Ocean thermocline depth reconstructions for the last glacial maximum. Paleoceanography 12:395-413

Ashworth AC, Hoganson JW (1993) The magnitude and rapidity of the climate change marking the end of the Pleistocene in the mid-latitudes of South America. Palaeogeogr Palaeoclimatol Palaeoecol 101:263-270

Bennett KD, Haberle SG, Lumley SH (2000) The Last Glacial-Holocene Transition in Southern Chile. Science 290:325-328

Blunier T, Brook EJ (2001) Timing of millennial-scale climate change in Antarctica and Greenland during the last glacial period. Science 291:109-112

Clark PU, Alley RB, Pollard D (1999) Northern Hemisphere ice-sheet influences on global climate change. Science 286:1104-1111

Clark PU, McCabe AM, Mix AC, Weaver AJ (2004) Rapid rise of sea level 19,000 years ago and its global implications. Science 304:1141-1144

De Pol-Holz R, Ulloa O, Dezileau L et al (2006) Melting of the Patagonian Ice Sheet and deglacial perturbations of the nitrogen cycle in the eastern South Pacific. Geophys Res Lett 33: L04704

De Pol-Holz R., Ulloa O., Lamy F. et al (2007) Late Quaternary variability of sedimentary nitrogen isotopes in the eastern South Pacific Ocean. Paleoceanography 22(2): PA2207

Delmonte B, Petit J, Maggi V (2002) Glacial to Holocene implications of the new 27000-year dust record from the EPICA Dome C (East Antarctica) ice core. Clim Dyn 18:647-660

Denton GH, Heusser CJ, Lowell TV et al (1999a) Interhemispheric linkage of paleoclimate during the last glaciation. Geografiska Annaler Series a-Physical Geography 81A:107-153

Denton GH, Lowell TV, Heusser CJ et al (1999b) Geomorphology, stratigraphy, and radiocarbon chronology of Llanquihue drift in the area of the southern Lake District, Seno Reloncavi, and Isla Grande de Chiloe, Chile. Geog Ann 81A:167-229

Dezileau L., Ulloa O., Hebbeln D. et al (2004) Iron control of past productivity in the coastal upwelling system off the Atacama Desert, Chile. Paleoceanography 19: PA3012

EPICA Community Members (2004) Eight glacial cycles from an Antarctic ice core. Nature 429:623-628

EPICA Community Members (2006) One-to-one coupling of glacial climate variability in Greenland and Antarctica. Nature 444:195-198

Feldberg MJ, Mix AC (2003) Planktonic foraminifera, sea surface temperatures, and mechanisms of oceanic change in the Peru and south equatorial currents, 0-150 ka BP. Paleoceanography 18: art. no.-1016

Glasser NF, Harrison S, Winchester V, Aniya M (2004) Late Pleistocene and Holocene palaeoclimate and glacier fluctuations in Patagonia. Glob Planet Change 43:79-101

Hajdas I, Bonani G, Moreno PI, Ariztegui D (2003) Precise radiocarbon dating of Late-Glacial cooling in mid-latitude South America. Quat Res 59:70-78

Hebbeln D, Shipboard Scientists (1995) Cruise report of R/V Sonne Cruise SO-102, Valparaiso (Chile) - Valparaiso (Chile). May 09-June 28, 1995. Berichte, Fachbereich Geowissenschaften, Universität Bremen, Bremen

Hebbeln D, Marchant M, Wefer G (2002) Paleoproductivity in the southern Peru-Chile Current through the last 33,000 years. Mar Geol 186:487-504

Hebbeln D, Lamy F, Mohtadi M, Echtler H (2007) Tracing the impact of glacial-interglacial climate variability on erosion of the southern Andes. Geology 35:131-134

Heusser C (2003) Ice age southern andes - a chronicle of paleoecological events. Elsevier Science, Amsterdam

Heusser L, Heusser C (2006) Submillennial palynology and palaeoecology of the last glaciation at Taiquemo ( $\sim 50,000$ cal yr, MIS 2-4) in southern Chile. Quat Sci Rev 25:446-454

Heusser L, Heusser C, Pisias N (2006) Vegetation and climate dynamics of southern Chile during the past 50,000 years: results of ODP Site 1233 pollen analysis. Quat Sci Rev 25: 474-485

Hobbs JE, Lindesay JA, Bridgman HA (1998) Climates of the southern continents: present, past and future. John Wiley \& Sons Ltd, Chichester 
Hughen K, Lehman S, Southon J et al (2004) C-14 activity and global carbon cycle changes over the past 50,000 years. Science 303:202-207

Hulton NRJ, Purves RS, McCulloch RD et al (2002) The Last Glacial Maximum and deglaciation in southern South America. Quat Sci Rev 21:233-241

Jenny B, Valero-Garces BL, Villa-Martinez R et al (2002) Early to Mid-Holocene Aridity in Central Chile and the Southern Westerlies: The Laguna Aculeo Record (34[deg]S). Quat Res $58: 160-170$

Jouzel J, et al (1995) The 2-Step Shape and Timing of the Last Deglaciation in Antarctica. Climate Dynamics 11(3):151-616

Kaiser J, Lamy F, Hebbeln D (2005) A 70-kyr sea surface temperature record off southern Chile (ODP Site 1233). Paleoceanography 20: PA1146

Kaiser J, Lamy F, Arz HW, Hebbeln D (2007) Dynamics of the millennial-scale sea surface temperature and Patagonian Ice Sheet fluctuations in southern Chile during the last 70kyr (ODP Site 1233). Quat Int 161:77-89

Kaplan MR, Ackert RP, Jr., Singer BS et al (2004) Cosmogenic nuclide chronology of millennialscale glacial advances during O-isotope stage 2 in Patagonia. Geol Soc Am Bull 116: 308-321

Kim JH, Schneider RR, Hebbeln D et al (2002) Last deglacial sea-surface temperature evolution in the Southeast Pacific compared to climate changes on the South American continent. Quat Sci Rev 21:2085-2097

Knorr G, Lohmann G (2003) Southern Ocean origin for the resumption of Atlantic thermohaline circulation during deglaciation. Nature 424:532-536

Knutti R, Flückiger J, Stocker T, Timmermann A (2004) Strong hemispheric coupling of glacial climate through freshwater discharge and ocean circulation. Nature 430:851-856

Koutavas A, Lynch-Stieglitz J, Marchitto TM Jr, Sachs JP (2002) El Niño-like pattern in ice age tropical Pacific sea surface temperature. Science 297:226-230

Lamy F, Hebbeln D, Wefer G (1998a) Late quaternary precessional cycles of terrigenous sediment input off the Norte Chico, Chile (27.5 degrees S) and palaeoclimatic implications. Palaeogeogr Palaeoclimatol Palaeoecol 141:233-251

Lamy F, Hebbeln D, Wefer G (1998b) Terrigenous sediment supply along the Chilean continental margin: modern regional patterns of texture and composition Geol Rundsch 87:477-494

Lamy F, Hebbeln D, Wefer G (1999) High-resolution marine record of climatic change in midlatitude Chile during the last 28,000 years based on terrigenous sediment parameters. Quat Res 51:83-93

Lamy F, Klump J, Hebbeln D, Wefer G (2000) Late Quaternary rapid climate change in northern Chile. Terra Nova 12:8-13

Lamy F, Hebbeln D, Rohl U, Wefer G (2001) Holocene rainfall variability in southern Chile: a marine record of latitudinal shifts of the Southern Westerlies. Earth Planet Sci Lett 185: 369-382

Lamy F, Rühlemann C, Hebbeln D, Wefer G (2002) High- and low-latitude climate control on the position of the southern Peru-Chile Current during the Holocene. Paleoceanography 17:1028

Lamy F, Kaiser J, Ninnemann U et al (2004) Antarctic Timing of Surface Water Changes off Chile and Patagonian Ice Sheet Response. Science 304:1959-1962

Lamy F, Kaiser J, Arz HW et al (2007) Modulation of the bipolar seesaw in the southeast pacific during Termination 1. Earth Planet Sci Lett 259:400-413

Lea DW, Pak DK, Spero HJ (2000) Climate impact of late quaternary equatorial pacific sea surface temperature variations. Science 289:1719-1724

Lea DW, Pak DK, Belanger CL et al (2006) Paleoclimate history of Galápagos surface waters over the last 135,000 yr. Quat Sci Rev 25:1152-1167

Marchant M, Cecioni A, Figueroa S et al (2007) Marine geology, oceanography and climate. In: Moreno T, Gibbons W (eds) The geology of Chile. Ecological Society Special Publication, London 
Martinez I, Keigwin L, Barrows TT et al (2003) La Nina-like conditions in the eastern equatorial Pacific and a stronger Choco jet in the northern Andes during the last glaciation. Paleoceanography 18:1033

Martinez P, Lamy F, Robinson RR et al (2006) Atypical [delta]15 N variations at the southern boundary of the East Pacific oxygen minimum zone over the last 50 ka. Quat Sci Rev 25: 3017-3028

Masson-Delmotte V, Stenni B, Jouzel J (2004) Common millennial-scale variability of Antarctic and Southern Ocean temperatures during the past 5000 years reconstructed from the EPICA Dome C ice core. Holocene 14:145-151

Masson V, Vimeux F, Jouzel J et al (2000) Holocene climate variability in Antarctica based on 11 ice-core isotopic records. Quat Res 54:348-358

McManus J, Francois R, Gherardi J-M et al (2004) Collapse and rapid resumption of Atlantic meridional circulation linked to deglacial climate changes. Nature 428:834-837

Miller A (1976) The climate of Chile. In: Schwerdtfeger W (ed) World Survey of Climatology. Elsevier, Amsterdam

Mix AC, Bard E, Schneider R (2001) Environmental processes of the ice age: land, oceans, glaciers (EPILOG). Quat Sci Rev 20:627-657

Mix AC, Tiedemann R, Blum P, Shipboard Scientists (2003) Southeast Pacific paleoceanographic transects. Ocean Drilling Program, College Station, TX

Mohtadi M, Hebbeln D (2004) Mechanisms and variations of the paleoproductivity off northern Chile $\left(24^{\circ} \mathrm{S}-33^{\circ} \mathrm{S}\right)$ during the last 40,000 years. Paleoceanography 19: PA2023

Mohtadi M, Romero O, Hebbeln D (2004) Changing marine productivity off northern Chile during the past 19000 years: a multivariable approach. J Quat Sci 19:347-360

Monnin E, Indermuhle A, Dallenbach A et al (2001) Atmospheric $\mathrm{CO}_{2}$ concentrations over the last glacial termination. Science 291:112-114

Montecinos A, Aceituno P (2003) Seasonality of the ENSO-related rainfall variability in central Chile and associated circulation anomalies. J Clim 16:281-296

Moreno PI (2004) The Last Transition from extreme glacial to extreme interglacial climate in NW Patagonia: regional and global implications. Eos Trans AGU, 85 (47). Fall Meet. Suppl.,

Moreno PI, Jacobson GL, Lowell TV, Denton GH (2001) Interhemispheric climate links revealed by a late-glacial cooling episode in southern Chile. Nature 409:804-808

Morgan V, et al (2002) Relative timing of deglacial climate events in Antarctica and Greenland. Science 297(5588):1862-1864.

Moy CM, Seltzer GO, Rodbell DT, Anderson DM (2002) Variability of El Nino/Southern Oscillation activity at millennial timescales during the Holocene epoch. Nature 420: $162-165$

Müller P. J., Kirst G., Ruhland G. et al (1998) Calibration of the alkenone paleotemperature index $\mathrm{UK}^{\prime} 37$ based on core-tops from the eastern South Atlantic and the global ocean $\left(60^{\circ} \mathrm{N}-60^{\circ} \mathrm{S}\right)$. Geochim Cosmochim Acta 62:1757-1772.

Ninnemann US, Charles CD (1997) Regional differences in Quaternary Subantarctic nutrient cycling: link to intermediate and deep water ventilation. Paleoceanography 12:560-567

Palmer MR, Pearson PN (2003) A 23,000-year record of surface water pH and PCO2 in the western Equatorial Pacific ocean. Science 300:480-482

Pisias N, Heusser L, Heusser C et al (2006) Radiolaria and pollen records from 0 to $50 \mathrm{ka}$ at ODP Site 1233: continental and marine climate records from the Southeast Pacific: Quat Sci Rev 25:455-473

Reimer PJ, Baillie MGL, Bard E et al (2004) IntCal04 terrestrial radiocarbon age calibration, 26-0 ka BP. Radiocarbon 46:1029-1058

Rein B, Lückge A, Reinhardt L et al (2005) El Nino variability off Peru during the last 20,000 years. Paleoceanography 20: Pa1099

Rinterknecht VR, Clark PU, Raisbeck GM et al (2006) The Last Deglaciation of the Southeastern Sector of the Scandinavian Ice Sheet. Science 311:1449-1452

Robinson R. S., Mix A., Martinez P. (2007) Southern Ocean control on the extent of denitrification in the southeast Pacific over the last 70 ka. Quat Sci Rev 26:201-212. 
Romero OE, Kim JH, Hebbeln D (2006) Paleoproductivity evolution off central Chile from the Last Glacial Maximum to the Early Holocene. Quat Res 65:519-525

Ruttlant J, Fuenzalida R (1991) Synoptic aspects of the central Chile rainfall variability associated with the Southern Oscillation. Int J Climatol 11:63-76

Sarnthein M, Kiefer T, Grootes PM et al (2006) Warmings in the far northwestern Pacific promoted pre-Clovis immigration to America during Heinrich event 1. Geology 34:141-144

Schmittner A, Yoshimori M, Weaver AJ (2002) Instability of Glacial Climate in a Model of the Ocean- Atmosphere-Cryosphere System. Science 295:1489-1493

Scholl DW, Christensen MN, Von Huene R, Marlow M, S (1970) Peru-Chile Trench. Sediments and sea-floor spreading. Geol Soc Am Bull 81:1339-1360

Shin SI, Liu Z, Otto-Bliesner B et al (2003) A simulation of the last glacial maximum climate using the NCAR-CCSM. Clim Dyn 20:127-151

Siddall M, Stocker TF, Blunier T et al (2006) Using a maximum simplicity paleoclimate model to simulate millennial variability during the last four glacial cycles. Quat Sci Rev 25:3185-3197

Sudgen DE et al (2005) Late-Glacial glacier events in southernmost South America: A blend of 'Northern' and 'Southern' hemispheric climatic signals? Geografiska Annaler: Series A. Phy Geography 87(2):273-288

Steig EJ, Hart CH, White JWC et al (1998) Changes in climate, ocean and ice-sheet conditions in the Ross embayment, Antarctica, at $6 \mathrm{ka}$. Ann Glaciol 27:305-310

Stocker TF (1998) Climate change - The seesaw effect. Science 282:61-62

Stocker TF, Johnsen SJ (2003) A minimum thermodynamic model for the bipolar seesaw. Paleoceanography 18:1087

Stott L, Cannariato K, Thunell R et al (2004) Decline of surface temperature and salinity in the western tropical Pacific Ocean in the Holocene epoch. Nature 430:56-59

Stott L, Timmermann A, Thunell R (2007) Southern hemisphere and deep-sea warming led deglacial atmospheric $\mathrm{CO}_{2}$ rise and tropical warming. Science 318:435-438

Streten NA, Zillman JW (1984) Climate of the South Pacific. In: van Loon H (ed) Climates of the oceans pp 26-429). Elsevier Sci., New York

Strub PT, Mesias JM, Montecino V et al (1998) Coastal ocean circulation off Western South America. In: Robinson AR, Brink KH (eds) The global coastal ocean. Regional studies and syntheses pp 273-315). Wiley, New York

Stuut J-BW, Lamy F (2004) Climate variability at the southern boundaries of the Namib (southwestern Africa) and Atacama (northern Chile) coastal deserts during the last 120,000 yr. Quat Res 62:301-309

Stuut JBW, Marchant M, Kaiser J et al (2006) The late Quaternary paleoenvironment of Chile as seen from marine archives. Geogr Helv 61:135-151

Thompson LG, Mosley-Thompson E, Davis ME et al (1995) Late Glacial stage and Holocene tropical ice core records from Huascaran, Peru. Science 269:46-50

Thompson LG, Davis ME, Mosley-Thompson E et al (1998) A 25,000 year tropical climate history from the Bolivian ice cores. Science 282:1858-1864

Thornburg T, Kulm LD (1987a) Sedimentation in the Chile Trench: depositional morphologies, lithofacies and stratigraphy. Geol Soc Am Bull 98:33-52

Thornburg T, Kulm LD (1987b) Sedimentation in the Chile Trench: petrofacies and provenance. J Sediment Petrol 57:55-74

Timmermann A, Krebs U, Justino F et al (2005) Mechanisms for millennial-scale global synchronization during the last glacial period. Paleoceanography 20 :

Toggweiler JR, Rusell JL, Carson SR (2006) Midlatitude westerlies, atmospheric CO2, and climate change during ice ages. Paleoceanography 21: PA1154

Tomczak M, Godfrey JS (2003) Regional Oceanography: an Introduction. Daya Pub., Delhi

Trenberth KE (1991) Storm Tracks in the Southern Hemisphere. J Atmos Sci 48:2159-2178

Villagrán C, Varela J (1990) Palynological evidence for increased aridity on the Central Chilean coast during the Holocene. Quat Res 34:198-207 
Visser K, Thunell R, Stott L (2003) Magnitude and timing of temperature change in the IndoPacific warm pool during deglaciation. Nature 421:152-155

Weaver AJ, Saenko OA, Clark PU, Mitrovica JX (2003) Meltwater pulse 1A from Antarctica as a trigger of the bolling- allerod warm interval. Science 299:1709-1713

Yin JH (2005) A consistent poleward shift of the storm tracks in simulations of 21st century climate. Geophys Res Lett 32:L18701 